\title{
無尿症状を示した腹膜後腔 non-chromaffin
}

\section{paraganglioma 22 例}

$\begin{array}{ccccc} & \text { 池 } & \text { 内 } & \text { 隆 } & \text { 夫 } \\ \text { 昭和大学医学部泌尿器科教室 } & \text { 依 } & \text { 出 } & \text { 丞 } & \text { 司 } \\ \text { (主任: 今村一男教授) } & \text { 吉 } & \text { 思 } & \text { 英 } & \text { 機 } \\ & \text { 今 } & \text { 村 } & \text { 一 } & \text { 男 }\end{array}$

\section{TWO CASES OF RETROPERITONEAL NON-CHROMAFFIN PARAGANGLIOMA WITH SYMPTOMS OF ANURIA}

\author{
Takao Ikeuchi, Shoji Yoda, Hideki Yoshida and Kazuo Imamura \\ Department of Urology, School of Medicine, Showa University
}

(Director: Prof. K. Imamura)

The cases of retroperitoneal non-chromaffin paraganglioma with symptoms of anuria were reported. A total of 15 cases, including these 2 cases of ours, of paraganglioma which occurred in retroperitoneum and had no symptoms of hypertension were collected as the cases examined in our country; 10 cases were confirmed as non-chromaffin paraganglioma.

要旨：われわれは，無尿症状を示した腹膜後腔 non-chromaffin paraganglioma の 2 症例を経験した. あわせて 腹膜後腔に発生した paraganglioma で, 高血圧などの症状を示さなかつた本邦報告例として, 自験例 2 例を含 めて15例を集計した.このうち non-chromaffin paraganglioma として確認できたものは10例であつた.

\section{緒言}

腹膜後腔に発生する non-chromaffin paraganglioma は 非常に稀な腫瘍であり，一般的に高血圧などのホルモン 活性症状を示さず無症状に経過し, 腹部腫瘤として気 付かれて発見が遅れる場合が多い，われわれは無尿ある いは尿量減少を主訴とし, 腹膜後腔の paraganglionよ り発生し, 悪性の経過をとつた non-chromaffin paraganglioma の 2 例を経験したので, 若干の文献的考察を加 壳て報告する。

\section{症例}

[应例 1 ]

患者: S.T. 56歳, 男性, 会社員.

主訴：無尿

家族歴・既往歴：特記すべきことはない。

現病歴：昭和48年 3 月 10 日頃より左腎部に重苦しい疼 痛が出現し, その後右腎部にも同様の疼痛を感じたとい 5。その頃より㽷量が減少してきたため 3 月29日に某院 を受診，尿青症を指摘され治療を受けていたが改善せ
ず，無尿となつたので 4 月 2 日当科を紹介されて来院し た。

初診時所見：栄養状態やや低下，眼検結膜は貧血状で あるが黄疸はなく, 胸部に全般的にラ音を聴取した。腹 部は平担で軟らかく, 腫瘤を触れず, 両腎も触知しなか つた，尿管走行部，膀脱部共に異常なく，外性器も異常 を認めなかつた，前立腺は小鷄卵大で弾性軟，左葉に小 結節を数個触知したが，圧痛はなかつた。

入院後経過 : 初診後直ちに入院, 尿管カテーテル法を 施行した. 膀胼鏡検査では容量 $300 \mathrm{cc}$, 両側尿管口周囲 に浮腫を認める他は異常なく, インジゴカルミン排泄試 験では両側とも15分で排泄をみなかつた，尿管カテーテ ル法では両側共 $25 \mathrm{~cm}$ 挿入可能で, 両側尿管カテーテル より尿の流出を認めた，尿管カテーテルをそのまま留置 し，5月 8 日左腎瘦術を施行したが術後尿毒症の状態が 改善されないまま 5 月24日鬼籍に入つた。

臨床検查. 戊 績: 血压; 176 78mmHg. 血沈値; 1 時 間 $33 \mathrm{~mm}, 2$ 時間值 $71 \mathrm{~mm}$. 尿所見; 蛋白 $(-)$, 糖 $(-)$, 
赤血球 (一), 白血球 $(-)$, 細菌 (一). 血液一般; IIII 色素量 $6.0 \mathrm{~g} / \mathrm{dl}$, 赤血球数 $178 \times 10^{4}$, メマトクリット值 $18 \%$, 白血球数 8,400 (好中球 $87.5 \%$, 好酸球 $1.5 \%$, 好 塩基球 $4.5 \%$, 単球 $6.5 \%$ ）血小板数 19,170 . 血液生化学 的検查; 尿素窒素 $132.6 \mathrm{mg} / \mathrm{dl}$, クレアチニン $21.0 \mathrm{mg} / \mathrm{d} 1$, 尿酸 $11.7 \mathrm{mg} / \mathrm{dl}, \mathrm{Na} 136 \mathrm{mEq} / l, \mathrm{~K} 7.6 \mathrm{mEq} / l, C l \quad 100$ $\mathrm{mEq} / l, \mathrm{Ca} 7.2 \mathrm{mg} / \mathrm{dl}$, P $8.9 \mathrm{mg} / \mathrm{dl}$, 血清総埤白 $7.8 \mathrm{~g} / \mathrm{dl}$, $\mathrm{A} / \mathrm{G}$ 比 1.3 , 黄㾝指数 $4 \mathrm{U}$, 血清統ビリルビン正常, 統 コレステロール $145 \mathrm{mg} / \mathrm{dl}$, GOT 19U, GPT 9U, LDH 400U, ALP 1.8U (B-L), ACP $0.80 \mathrm{U}$ (B-L).

レントグン検查：腎部, 膀胱部単純撮影にて異常所見 を認めず，逆行性腎孟撮影にては両側尿管が周团より压 迫され，両腎共に下腎杯，腎而に陰影欠損定垫め，その 変化は特に左腎に著明であつた（図1).

\section{因 1 症例 1 逆行性腎盂撮影}

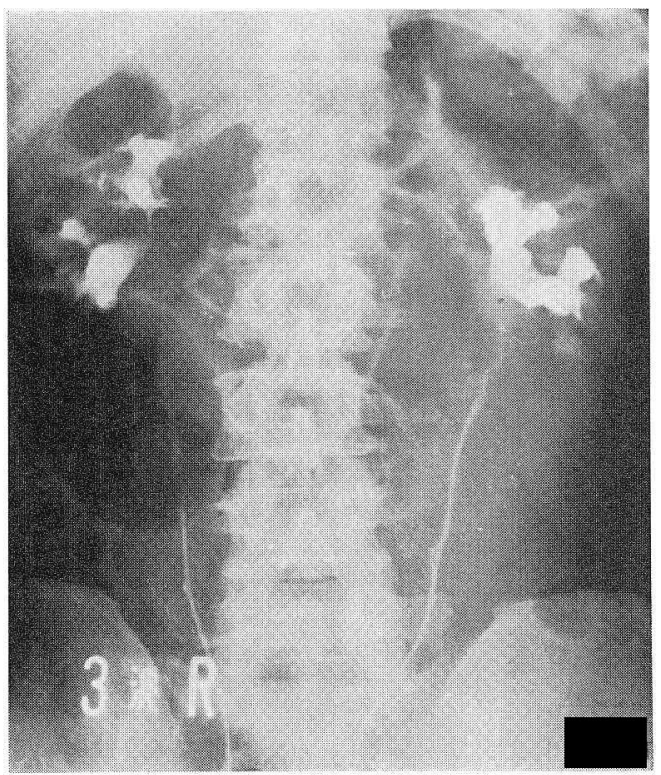

な和、レノグラムは測定不能でレノシンチグラムは描 出されなかつた。

手術所見：全麻のもとに左腰部斜切開で腹膜後腔に達 した，腹膜後腔は全般にわたり腫沮の浸潤を思わせる兏 白色の堅い板状の組織で満たされ, 腎周册も同様の組織 により全面覆れれていた，腫晹は易出血性で，腹謨，大 動脈などへの浸潤も著明で摘出不能であらたので, 病理 学的診断のため腫瘍の一部老切除し, 左腎瘦の久設置し 手術を終了した。
病理組織所見：好酸性に染をる核小体をもつ，大型の 明るい核をもつた大きな細胞が胞巣状の構造をとりなが ら増殖している(成2).

\section{因 2 症例 1 病理組織所見}

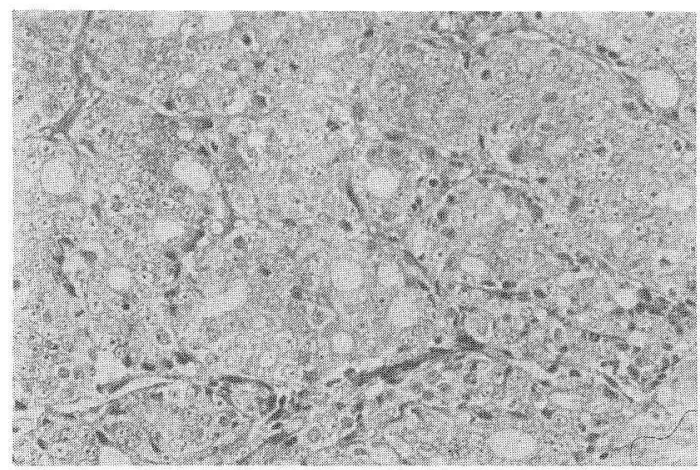

本標本はホルマリン固定のためのクローム反庆は施 行しえなかつたが，組織学的所見より non-chromaffin paraganglioma と思われる。

[症例 2 ]

患者: Y.T. 43葴, 男性, 来務員.

主訴：厡量減少。

家族歴：特記寸べさことはない。

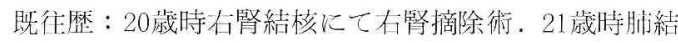
核にて左胸廓形成術.

現病歴和よび経過：昭和49年 8 月頃より左側腹部痛， 左腰痛が出現したため近定で鎮痛剂の投与を受けていた （当時，血液生化学検查で LDH は $700 \mathrm{U}$. と高值を示 していたといら）。しかし疼痛が改善しなからたので， 某大学病院整形外科を受診したが，ての原因は判然とし なかつたといら１１0月頃より下腹部不快感と尿量減少に 気づき11月 2 日当科走受診した。

初䛦時所見は，体格扣よび栄養状態中等度，眼眕結膜 はやや貧血状であるが黄疾はなく，左胸部に胸邡形成術 の手術洀痕があるが，聴打診では特に異常を認めない。 また，左側腹部にて婜臓劣腫瘤として触れ，左迫すると 下腹部に放散与る疼痛を認めた。外性器，前立腺などに は特に異常を認めなかつた。

初診後精查の目的にて入院したが，臨本検査成績は, 尿所見; 蛋白 (H), 糖 (一), 赤血球 (土), 白血球 (土), 細菌 (一). 血液一般初よび血液生化学的検查で は著変を認めず，血压も正労であつた。レントダン検查 ては，静脈性腎盂撮影にて左腎機能は正常で，腎盂，腎 
杯の陰影欠損，王迫像，崩壇像は認めなかつたが，左尿 管は上部で屈曲し，やや外側に圧排されている像を得た (図 3 ).

図 3 症例 2 静脈性腎点撮影

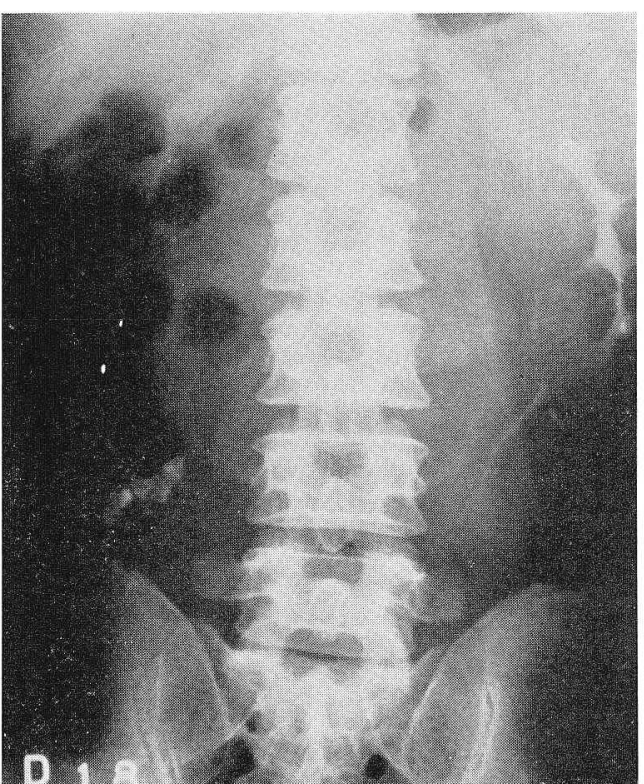

主訴の左側腹部痛や腰痛は鎮痛剂でュントロールて き，原量も增加したので11月5日退院したが，1週間後 上り突然全身に発疹が出現したため某大学病院内科に人 院した，人院後 $38 \mathrm{C}$ 前後の発熱が続き，再び尿量減少を 橤めたので同大学病院泌尿器科に沶いて逆行性腎血撮影 去施行したが，承管カテーテルは約 $4 \mathrm{~cm}$ で挿入不能 で，造影丳を注入しても尿管，腎盂は描出さ机なからた といら。また，この頃に左鎖骨窝リンパ節の腄瘤が発見 され，吸引細胞診の結果，腺癌様の腄陽細胞を認めたと のことであつた。

その後，泉毒症状態が進行し，腹膜㴶流在施行してい たが改善せず，人工透析の目的にて当科再入院した。 入院後人工透析老施行していたが効なく 12 月 4 日鬼籍に 入つた。

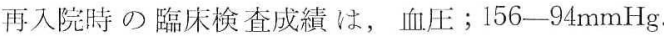
血沈值； 1 時間 $62 \mathrm{~mm} ， 2$ 時間95 $\mathrm{mm}$. 血液一般; 血色秦 量 $7.1 \mathrm{~g} / \mathrm{dl}$, 赤血球数 $253 \times 10^{4}$, ヘマトクリット值 $25 \%$, 白血球 43.600 （好中球 $89.5 \%$ ，好酸球 $0.5 \%$ ，好塩基 球 $1 \%$, 単球 $5 \%$, リンパ球 $4 \%$ ）血小板数 21,500 . 血 液生化学的検查; 尿素窒素 $79.0 \mathrm{mg} / \mathrm{d} 1$, クンチニン
$14.3 \mathrm{mg} / \mathrm{dl}$ ，尿酸 $6.29 \mathrm{mg} / \mathrm{dl} ， \mathrm{Na} 135 \mathrm{mEq} / l, \mathrm{~K} 6.7 \mathrm{mEq} / l$, $\mathrm{Cl} 90 \mathrm{mEq} / l$, Ca $8.74 \mathrm{mg} / \mathrm{dl} ，$ P $3.47 \mathrm{mg} / \mathrm{dl}$ ，而清総蛋当 $7.5 \mathrm{~g} / \mathrm{dl}, \mathrm{A} / \mathrm{G}$ 比 0.96 , 黄疸指数 $4 \mathrm{U}$ ，血清ビリルビン正 常，総コレステロール168mg/dl, GOT 26U, GPT 10U, LDH 761U, ALP 6.9U (B-L), ACP 1.3U (B L) であ りた.

病理解剖所見：左腹膜後腔に人頭大の灰白出，易出血 症の腫瘍を認め，腫瘍はビマン性に左腎実質，腎血，尿 管および膵臓に浸潤していた。また膵臓，肝蔵および胃 の周国リンパ節に転移を認め，さらに左鎖骨窄りン゚゚節

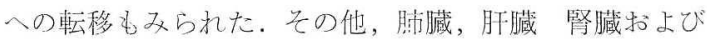
溹葴などの血管に腫痬塞栓を認めた（図 4).

\section{図 4 症例 2 病理解剖所見}

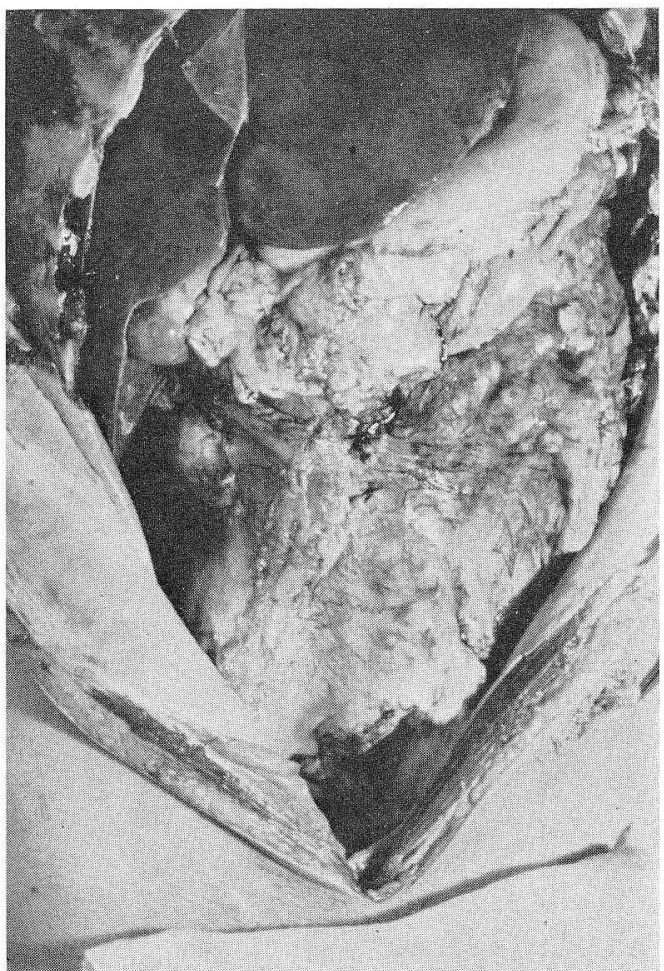

病理組織所見：大型の核小体を含主多型性，異型性の 强い腫瘍細胞が不規則な構造をもつてビマン性に増殖し ている(図 5). 本標本もホルマリン固定のためクロー ム反応は施行し总なかつたが，組織学的所見より nonchromaffin paraganglioma と思われる。

\section{考察}

所1)によると paraganglion とは本来の末梢神経系 
図 5 症例 2 病理組織所見

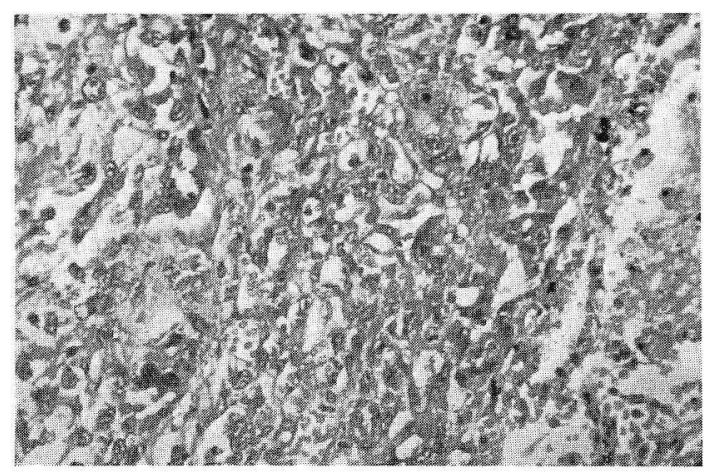

素之密接な発生上の関係を示すが，その構造は独特の变 化が加わつた特多な細胞集団で，したがつてその存在場 所は，末梢神経が全身にみられるごとくに全身に分布し ている。そして，それより発生する腫瘍の臨床像もまた 部位によりさまざまの趣きをもつよらになるといわれて いる.

paraganglion 組織に抒ける細胞の特徵として細胞体の クローム顆粒の存在があげられる。 chromaffinity はと の顆粒の存在によるもので，一般的に副交感神経系のも
のには証明されないが，交感神経系の paraganglion に はそれがタられ，特㨽腎髄質には著明であると言われ ている.

従来, 交感神経系の paraganglion より発生した腫瘍 はホルモン活動性であり，副交感神経系の paraganglion より発生した腫瘍は非活動性であるとされてきたが，高 安ら ${ }^{2)}$ は㖶瘍細胞の組織検査でクローム親和性であつた にもかかわらず臨床上ホルモン活性の認められなかつた 将例を報告し，ホルモン非活性内分泌腫瘍の概念につい て再検討なざきことを指摘した。また嶋崎ら゙はホルモ ソ活性走示した腹膜後腔 non-chromaffin paraganglioma の 1 生検例を報告し，非夕ローム親和性のものにもカ テュールアミン産生のものが見出されることを示した. non-chromaffin paraganglioma といら呼称は，1949年に Lattes $^{4)}$ が始めて 使用した言葉で, chromaffin paraganglioma との区別圭目的として使用したようである。 腹膜後腔に発生した non-chromaffin paraganglioma の 報告は，1951年に Smetana $5^{5)} \not 3$ malignant tumor of non-chromaffin paraganglioma として報告 した14症例 のなかと含まれた 4 例が最初の報告であり，その後に Christopherson $5^{\text {b) }}$ が Alveolar soft-part sarcoma の名の

表 1 腹膜後腔に登生し高血圧などの症状を示さなかつた paraganglioma 本邦報告例

\begin{tabular}{|c|c|c|c|c|c|c|c|}
\hline & 報告年度 & 報告者 & 年齢 & 性 & 主要症状 & 発生部位 & $\begin{array}{l}\text { ク口- } \\
\text { 親 和 性 }\end{array}$ \\
\hline 1 & 1965 & 金茾 ${ }^{10)}$ & 46 & 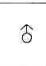 & $\begin{array}{l}\text { 腹部腫瘤 } \\
\text { 腹部䍍満 }\end{array}$ & 腹膜後腔 & + \\
\hline 2 & 1967 & 小池 ${ }^{11)}$ & 69 & 우 & 腹部胿隆 & 右副腎䯣質 & - \\
\hline 3 & 1968 & 高橋 ${ }^{12)}$ & 41 & $\delta$ & $\begin{array}{l}\text { 上腹部起渾感 } \\
\text { 右季肋部腄張 }\end{array}$ & $\begin{array}{l}\text { 腹膜後腔 } \\
\text { 右副腎 }\end{array}$ & $?$ \\
\hline 4 & 1968 & 高安 ${ }^{21}$ & 46 & $\delta$ & $\begin{array}{l}\text { 左腹部腫瘤 } \\
\text { 賓 血 }\end{array}$ & 左腹膜後腔 & + \\
\hline 5 & 1968 & 桐本 ${ }^{13)}$ & 24 & $\hat{o}$ & 腹部腫瘤 & 左腹膜後腔 & - \\
\hline 6 & 1970 & 稲田 ${ }^{14)}$ & 67 & $\delta$ & 右季肋部軽度膨隆 & 右腹膜後腔 & + \\
\hline 7 & 1971 & 桜井 ${ }^{8 !}$ & 13 & 우 & $\begin{array}{l}\text { 腹部腫瘤 } \\
\text { るいそう }\end{array}$ & 右腹膜後腔 & - \\
\hline 8 & 1973 & 千葉 ${ }^{15)}$ & 41 & 우 & $\begin{array}{l}\text { 腹部腫瘤 } \\
\text { 腹 痛 }\end{array}$ & 左腹膜後腔 & - \\
\hline 9 & 1976 & 福島 ${ }^{9 !}$ & 38 & 우 & 肛門 - 智部猯 & 仙骨前腹膜後腔 & - \\
\hline 10 & \multirow{3}{*}{1977} & \multirow{3}{*}{ 原 ${ }^{161}$} & 48 & 우 & $\begin{array}{l}\text { 右季肋部痛 } \\
\text { 発 熱 }\end{array}$ & 右腹腔後腔 & - \\
\hline 11 & & & 43 & 8 & 心窩部痛 & 腹膜後腔 & - \\
\hline 12 & & & 54 & 우 & 発 熱 & 腹膜後腔 & - \\
\hline 13 & 1979 & 日景 ${ }^{171}$ & 38 & $\$$ & 左季肋下腫瘤 & 左腹膜後腔 & $?$ \\
\hline 14 & \multirow{2}{*}{1981} & \multirow{2}{*}{ 自験例 } & 56 & $\hat{b}$ & 無 尿 & 腹膜後腔 & - \\
\hline 15 & & & 43 & $\hat{o}$ & 尿量減少 & 左腹膜後腔 & - \\
\hline
\end{tabular}


もとに12将例を報告し，导らに1969年に Olson ヴが白 験例老会めて21例を集計している。

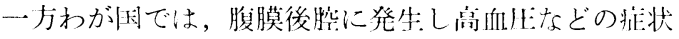
を寺さなかつた paragangliomaをして1971年に桜非らか が5 例を報告し，さらに1976年に福㟋ららが 7 例を集計 している。今同われが腹膜後腔に発生し，高血压な どの壮状を暑さなからた paraganglioma の本邦拉例とし て集計し得たものは，自験例の 2 例を含めて15将例であ つた（裴1）。しかし、これらの拈例の中にはクローム顆 粒の存在の们無に一いての剖載がイ明の斑例もあり，文

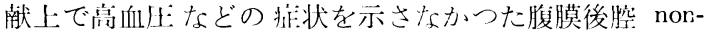
chromaffin paraganglioma として確認できたものは自駼 例を含め10例のスであつた。

non-chromaffin paraganglioma の組織構造について は, 所 ${ }^{1)}$ は paraganglioma の最も椟本的な性格は豊富な

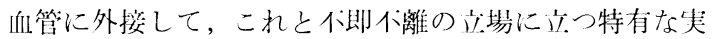
質紐胞の集塊に他ならないとし，これらに対し神経線維

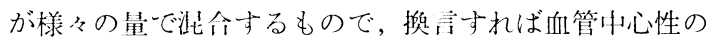
のの構成である，としている。そこで, 病理組織像で の共通した特徵としては, 腫陽細胞が多型性, 異型性で あるが，ほぼ円型で細胞質に富久，その配列は胞巣状構 造をなし，モ紐向管に富んだ網状の䦌質に接するように

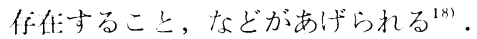

一方, chromaffinity は細胞体の”口ーム顆粒の位住: の有無によるが，諸家の结とんどの報售之间様に本为例 も最初にホルーリン沽定を行なつたためクローム漞和性 については明瞭には言いがたい。しかし HE 染色でも 細胞質に裀色顆粒が見られるといら報告もあり，その点 では，われわれの将例は観祭し它た限りで顆粒は涊めら れず，特徽的な将理組織学似所罗より non-chromaffin paraganglioma と骖断された.

non-chromaffin paraganglioma の曹性度に园して, Thacker ら ${ }^{19)}$ は臨休似には転移, 再発し, 蚛性と考えら れる将例が多いが, 組織学的には良性, 琹性の判断がつ

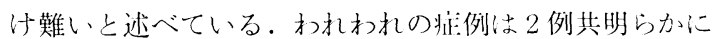
墨性の経過をたどり，特に为例 2 では重要蔵器への浸 潤，転移が著明であつた。

治療としては，今のところ一般の腹膜後腔腫陽と同梯 に外科的摘除による他に效果は無いようであるが，この 腫煌は血管と密接な関連をもち，易出血性で，しばしば 大動脈や大静脈と揄着している例もあり，先金摘除は小 なり困難なようである。

\section{結 語}

無疗あるいは㽷量減少を主訴とし特恭な経過をと一た 脑膜後腔 non-chromaffin paraganglioma の 2 例を報告

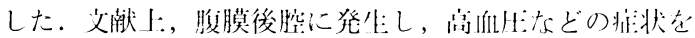
示さなかつた non-chromaffin paraganglioma として集 竍し得たものは, 本扼ではウ験例の 2 例を会めて10例で あった。

終りに、樆理組織学的彰断につきご教ふいいたたいたは

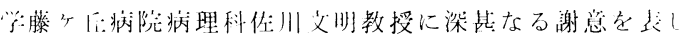

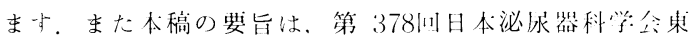
尔地分公に打いて奖交した。

\section{文献}

1) 所安犬：木梢神終系の腫煌の概観, 特に paraganglionとその腄瘍の内谷。脳之神経、7, $1-8.1955$

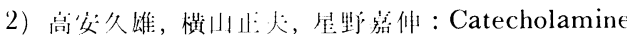
過剩分泌怔状を欠いた Malignant Paragnaglioma 甘本臨床，26，2104-2107，1968.

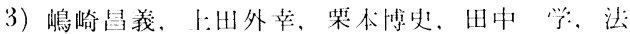
它盛光：ホルモン活性を小した後腹膜 Nonchromaffin Paraganglioma 01 生検例。日抦理公 志, 53, 163, 1964.

4) Lattes, R. and Walter, J.G.: Nonchromaffin paraganglioma of the middle ear. Cancer, 2, $447-468,1949$.

5) Smetana, H.F. and Scott, W.F. Jr.: Malignant tumors of nonchromaffin pasaganglioma paraganglia. Milit. Surg., 109, 330-349, 1951.

6) Christoperaton, W.M., Footh, F.W. Jr. and Stewart, F.W.: Alveolar soft-part sarcomas. Cancer, 5, 100-111, 1952.

7) Olson, J.R. and Abell, M.R.: Nonfunctional, nonchromaffin paragangliomas of the retroperitoneum. Cancer, 23, 1358--1367, 1969.

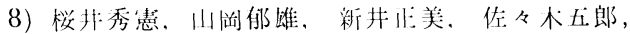

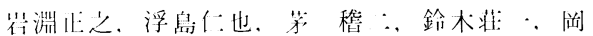
本则昭, 括幹崔： $1330 \mathrm{~g}$ の後腹膜 non-chromaffin daraganglioma $の$ 摘出に成功した 1 例に ついて。 H臨外医公誌, 32.63-69，1971。

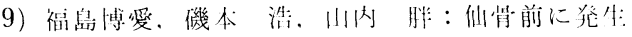
した Paraganglioma の 1 于術経験。臨床外科, 31. 687-691, 1976.

10）金井弘, 阿部富男, 武滕輝 , 遠藤三郎：後 腹膜腔に焱生せる Paraganglioma の 1 治験例。 僡の臨术，11，701-705，1965。

11) 小池分郎、横川忙之：日大な Paragnglioma の 1 例。臨泌, 21, 676-677, 1967.

12 ) 㕿橋親彦, 本多雅昭：巨大なる後腹膜 Paragan-

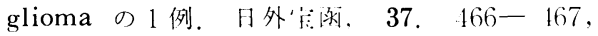
1968. 
13) 桐本孝次, 杉本顕俊：父子に見られた Paraganglioma の剖検例. 日病理会誌, 57, 211, 1968.

14) 稲田俊雄, 岡田耕市, 高木健太郎, 大和田文 雄, 有輪六郎: Paraganglioma の 1 例. 日泌尿 会誌, $61,100,1970$.

15）千葉庸夫, 大内 博, 渡辺至, 大原倒, 葛 西森夫：後腹膜に発生した Paraganglioma の 1 例. 外科, 35, 309-312, 1973.

16）原 啓一, 重松貞雄, 是久博見, 森岡恭彦, 菅 原克彦: 肝癌を疑つた後腹膜 Paraganglioma の 3 例. 日消外会誌, 10, 293-299, 1977.

17）日景高志, 三橋慎一, 平岡 真, 熊谷 章, 外
間孝雄 : 後腹膜 nonfunctional paraganglioma の 1 例. 日泌尿会誌, 70, 1177, 1979.

18) George, G.G. and Philip, M.G.: Tumors of the EXTRA-ADRENAL PARAGANGLION SYSTEM (INCLUDING CHEMORECEPTORS), ATLAS OF TUMOR PATHOLOGY (Second Series, Fascicle 9), 1973.

19) Thacker, W.C. and Duckworth, J.K.: Chemodectoma of the orbit. Cancer, 23,1233 -1238, 1969. 